\title{
TRANSFERABILITY OF SSR MARKERS FROM RELATED FICUS SPECIES TO FICUS CARICA L. AND ASSESSMENT OF EFFECTIVENESS OF THE MARKERS
}

\author{
IKTEN, H.* - SOLAK, S. S. - YILMAZ, Y. \\ Department of Agricultural Biotechnology, Faculty of Agriculture, Akdeniz University \\ 07070 Antalya, Turkey \\ *Corresponding author \\ e-mail: haticeikten@akdeniz.edu.tr \\ (Received $12^{\text {th }}$ Jan 2018; accepted $13^{\text {th }}$ Mar 2018)
}

\begin{abstract}
The objective of the study was to test the transferability of previously developed SSR markers for different Ficus species to Ficus carica. A total of 54 SSR simple sequence repeats (SSRs) primers previously developed for Ficus montana, $F$. septica, F. sycomorus, $F$. (sycomorus) racemosa, $F$. (urostigma) rubiginosa, and F. insipida were tested on $32 \mathrm{fig}$ (Ficus carica L.) genotypes. Out of 54, 38 primers amplified the genomic DNA of Ficus carica genotypes, while the remaining 16 primers showed either no amplification or unreadable gel images. Out of 38, 17 primers were polymorphic and produced 62 alleles with an average of 3.64 bands per locus. The transferability rate from different Ficus species to Ficus carica varied from $90.9 \%$ (F. rubiginosa and F. racemosa) to $33.3 \%$ (F. septica). Some of the primers from donor species namely Frac13, Frac83, Frac241, Fsyc07, FinsA1, FM4-15, and FM4-70 resulted in similar banding patterns in the Ficus carica genome, suggesting that they were developed from the same loci and primer binding sites are conserved. Three loci (Fsyc11, FinsQ5 and FinsN3) produced more alleles in Ficus carica than donor species. Sixty-two SSR alleles, could distinguish all fig genotypes thoroughly, and UPGMA cluster analysis grouped them into two groups. As a conclusion, 17 primers developed for related Ficus species successfully amplified polymorphic bands in Ficus carica and distinguished all fig genotypes thoroughly. The transferability of SSRs to Ficus carica from related species affirmed the possibility of being used of these markers for genetic diversity, mapping and comparative genetic analysis.
\end{abstract}

Keywords: fig, microsatellite markers, molecular characterization, genetic diversity, genetic relationship

\section{Introduction}

Fig (Ficus carica L.), one of the oldest fruit crops in the world, belongs to the family of Moraceae which includes 60 genera and more than 2000 species of trees, shrubs and herbs. The genus Ficus includes over 1000 species classified into about 48 subgenera (Condit, 1969; Storey, 1975). There are two basic types of figs: caprifig and edible figs. Caprifig bear both male and female flowers whereas edible figs bear only female flowers. The only Ficus species cultivated for their fruits are the $F$. carica and $F$. sycamorus. Ficus carica L. is cross-pollinated and has a diploid $(2 \mathrm{n}=26)$ genome (Darlington and Wylie, 1955).

There are limited numbers of researches in Ficus carica aiming to understand the genome structure and determine the genetic character of genetic sources. Molecular markers are useful tools for genetic diversity, population structure and genetic mapping studies. There are also morphological and biochemical methods for detection of genetic variations, however being limitless and not affected by growing stage of the plant and environmental conditions makes molecular markers preferable (Rahnavard, 2016). There are different molecular marker systems such as random amplified polymorphic DNA (RAPD), sequence-related amplified polymorphism (SRAP), amplified fragment 
length polymorphism (AFLP) and simple sequence repeat (SSR) used for determination of genetic variation among the plant genotypes. Microsatellite markers (simple sequence repeats- SSR) are widely used marker systems since they are reliable, codominant, highly polymorphic and suitable for automation. However microsatellite markers are species-specific and developing SSR markers is time consuming and expensive. SSR primers developed for one species could be transferred into related species. There have been several reports on the transferability of SSR markers among the related crops (Pierantoni et al., 2004; Gasic et al., 2009; Mnejja et al., 2010; Fan et al., 2013). Transferability of SSR markers among the Ficus species is significant in the previous studies. Giraldo et al. (2005) evaluated 26 SSR markers in 13 different Ficus species. Nazareno et al. (2009) tested 15 microsatellite loci, previously developed for Ficus (Pharmacosycea) insipida, Ficus (Sycomorus) racemosa and Ficus (Urostigma) rubiginosa for cross amplification in specimens of $F$. citrifolia and $F$. eximia. Heer et al. (2012) developed seven primers from Expressed sequence taq (ETS) libraries of $F$. citrifolia and $F$. popenoei (subgen. Urostigma sect. Americana) and successfully transferred these markers along with five previously developed anonymous loci to basal subgenus Pharmacosycea sect. Pharmacosycea and seven species of the derived subgenus Urostigma ( $F$. citrifolia, $F$. colubrinae, $F$. costaricana, $F$. nymphaeifolia, $F$. obtusifolia, $F$. pertusa, and $F$. popenoei).

The usefulness of the transferred markers was also tested for estimating the genetic diversity and relationships of the population in the above mentioned studies and current study. The choice of the effective marker is very important for phylogenetic, genetic mapping and evolutionary genetic studies for achieving effective and reliable results. The amplification performance of the marker is measured by producing reliable, repeatable and polymorphic fragments.

The objective of the current study was to examine the transferability of 54 SSR markers previously developed for $F$. montana, F. septica (Zavodna et al., 2005), $F$. sycomorus (Ahmed et al., 2007), F. (Sycomorus) racemosa, F. (Urostigma) rubiginosa (Crozier et al., 2007) and F. insipida (Vignes et al., 2006) to Ficus carica. To ensure the effectiveness of the markers, all successfully transferred microsatellites have been evaluated for determining genetic diversity and relationship among the 32 fig genotypes (Ficus carica L.).

\section{Material and method}

\section{Plant material and DNA extraction}

Total genomic DNA was extracted from young, frozen leaves of 32 genotypes (16 male, 16 female) previously collected from trees located at Fig Research Center, Aydin, Turkey and kept at $-20{ }^{\circ} \mathrm{C}$. DNA extraction was performed based on the modified cetyltrimethylammonium bromide (CTAB) method (Doyle and Doyle, 1990). DNA samples were electrophoresed on $1 \%$ agarose gels stained with ethidium bromide and adjusted to $30 \mathrm{ng} / \mu \mathrm{l}$ final concentrations.

\section{Amplification conditions}

Initially 54 SSR markers were screened using four genotypes to see the amplification performance. The PCR with the non- amplified primers was repeated. Then based on amplification performance 38 primers across all 32 genotypes were selected to be used. 
Polymerase chain reactions (PCRs) were performed in a total volume of $15 \mu \mathrm{l}$ containing $30 \mathrm{ng} / \mu \mathrm{l}$ genomic DNA template, $1 \mu \mathrm{l}$ of $10 \times \mathrm{PCR}$ buffer, $1 \mu \mathrm{l}$ of $2.5 \mathrm{mM}$ dNTP mixture, $1 \mu \mathrm{l}$ of $25 \mathrm{mM} \mathrm{MgCl} 2,0.5 \mu \mathrm{l}$ each of forward and reverse primer (10 $\mathrm{pmol} / \mu \mathrm{l}$ ), and $0.1 \mu \mathrm{l}$ of $5 \mathrm{U} / \mu \mathrm{l}$ Taq polymerase. Labeled primers were used (IRD700 and IRD800) following the protocol described by Schuelke (2000). Forward primers were labeled with a adaptor sequences (GGAAACAGCTATGACCAT) at its 5' end. The reactions were performed with the following conditions: $94{ }^{\circ} \mathrm{C}$ for $3 \mathrm{~min}$, then 35 cycles of $94{ }^{\circ} \mathrm{C}$ for $40 \mathrm{~s}, 53-65{ }^{\circ} \mathrm{C}$ for $50 \mathrm{~s}$, and $72{ }^{\circ} \mathrm{C}$ for $1 \mathrm{~min}$, and a final step at $72{ }^{\circ} \mathrm{C}$ for $10 \mathrm{~min}$. PCR products $(15 \mu \mathrm{l})$ were mixed with $50 \mu \mathrm{l}$ formamide loading buffer $(98 \%$ formamide, $10 \mathrm{mM}$ EDTA, $0.25 \%$ bromophenol blue, $0.25 \%$ xylenecyanol, $\mathrm{pH} 8.0$ ) and denatured for $3 \mathrm{~min}$ at $95{ }^{\circ} \mathrm{C}$, and cooled on ice. Separation was performed on a Li-Cor $\mathrm{IR}^{2} 4200$ Genetic Analyzer (Li-Cor Biosciences) using 5.5\% denaturing polyacrylamide gel on $25 \mathrm{~cm}$ plate.

\section{Data analysis}

Only reproducible bands with high intensity were scored as present (1) or absent (0). The genetic similarity matrix was calculated using Numerical Taxonomy Multivariate Analysis System (NTSYS-pc) version 2, 1 software package (Exeter Software, Setauket, NY, USA) (Rohlf, 2000). Based on the similarity matrix, a dendrogram showing the genetic relationships between genotypes was constructed by the unweighted pair group method with arithmetic average (UPGMA) using SAHN module of the software NTSYSpc. In addition, principal component analysis (PCA) was performed using the EIGEN and PROJ modules based on Jaccard's similarity coefficient.

The transferability (amplification rate) of SSR marker developed for each donor species were calculated by counting the amplified markers in Ficus carica regardless of polymorphism according to formula by Kuleung et al.(2004) (Eq. 1):

$$
\text { Amplification }(\%)=\text { number of amplified markers } x 100 / \text { total number of markers (Eq.1) }
$$

\section{Results}

A total of 54 SSR markers were screened with four genotypes for amplification performance and 38 microsatellites were successfully amplified. Thirty-eight SSR loci were then employed to detect genetic diversity and relationship among the 32 Ficus carica genotypes and a total of 89 alleles were produced with the 2.34 average alleles per locus. In the present study, of the 38 loci transferred, 21 of which were monomorphic and 17 were polymorphic for Ficus carica and produced 62 alleles. The number of polymorphic bands per SSR locus ranged from 2 to 14 with a mean of 3.64 alleles per locus. The sizes of the fragments ranged from 110 to $310 \mathrm{bp}$. The primer FM4-15 produced highest number of band (14) in Ficus carica comparing the other primers, indicating amplification of more than two loci (Table 1).

Similarity matrix was used to study genetic diversity among 32 genotypes. The highest value of similarity was 0.80 found between the genotypes 'Noire de Caromb' and 'Kavak' and genotypes 'Armut ilek'and 'Bostanc1'. Minimum similarity value was 0.47 between genotypes 'Buyukkonkur' and 'Morözer'. To test the usefulness of the transferred primers for analysis of genetic diversity on Ficus carica population the clustering pattern of the genotypes was assessed. 
Table 1. Transferability and characterization of Ficus racemosa and Ficus rubiginosa (Crozier et al., 2007), Ficus sycomorus (Ahmed et al., 2007), Ficus insipida (Vignes et al., 2006), F. montana and F. septica ((Zavodna et al., 2005) SSR loci in 32 Ficus carica genotypes

\begin{tabular}{|c|c|c|c|c|c|}
\hline $\begin{array}{l}\text { Microsatellite } \\
\text { marker }\end{array}$ & Species & Primer sequence $\left(5^{\prime}-3^{\prime}\right)$ & TA & $\mathbf{P A}$ & $\begin{array}{c}\text { Product } \\
\text { length }\end{array}$ \\
\hline Frac13 & F. racemose & $\begin{array}{c}\text { F: CACGTTCACGCTGCAAACT } \\
\text { R:GATAGAGAAGGCATATCCAGAG }\end{array}$ & 4 & 4 & $127-141$ \\
\hline Frac29 & F. racemose & $\begin{array}{l}\text { F: CCAGGCATATGCATCTTGTGTA } \\
\text { R: CTCGCAGCTTTCCTCGCA }\end{array}$ & 1 & M & 200 \\
\hline Frac83 & F. racemose & $\begin{array}{c}\text { F: TGAACCTTCAATAACATCGGGTT } \\
\text { R: CTCATGCAATCATAGCACTCA }\end{array}$ & 3 & 3 & $175-225$ \\
\hline Frac86 & F. racemose & $\begin{array}{c}\text { F: TGTCACTGTTCTGTTTGTGC } \\
\text { R: CAGCCAACCCTCAAGTATAAGA }\end{array}$ & 1 & M & 180 \\
\hline Frac110 & F. racemose & $\begin{array}{l}\text { F: CCAGAACAGGTTGGACGTAAC } \\
\text { R: GGATTACCCGCGCTATGAAGT }\end{array}$ & 1 & M & 240 \\
\hline Frac113 & F. racemose & $\begin{array}{l}\text { F: CTGGGTCCTCTCTATTACCAAC } \\
\text { R: GCTGATCTTCTCGGATGCT }\end{array}$ & 3 & 3 & $231-233$ \\
\hline Frac154 & F. racemose & $\begin{array}{l}\text { F: ACCCAAGAGCCCAAACTCGT } \\
\text { R: TCAACCCTTGTGCTCCTTGC }\end{array}$ & NA & & - \\
\hline Frac202 & F. racemose & $\begin{array}{l}\text { F: AGAGATATGATGTTCTAGTGCA } \\
\text { R: CTCGCTCCCACTTAAATACAAG }\end{array}$ & 1 & M & 200 \\
\hline Frac222 & F. racemose & $\begin{array}{l}\text { F: ACCCATATAGCAGTCTTCAGA } \\
\text { R: GCTTGTTGACTCCGCAACTA }\end{array}$ & 1 & M & 215 \\
\hline Frac241 & F. racemose & $\begin{array}{c}\text { F: GGCTCAAGCAAGGGATGGA } \\
\text { R: CGAGCTCATTTGTTTATCGACC }\end{array}$ & 3 & 3 & $280-294$ \\
\hline Frac244 & F. racemose & $\begin{array}{c}\text { F: ACCTAGAATCATAACCCTTCA } \\
\text { R: CCCATAAACTACGATACATAAGA }\end{array}$ & 1 & M & 310 \\
\hline Frub29 & F.rubiginosa & $\begin{array}{l}\text { F: CCACTTTGGAATGTCACTTGGA } \\
\text { R: TGAACACGCCAACTGAGAATG }\end{array}$ & 1 & M & 225 \\
\hline Frub38 & F.rubiginosa & $\begin{array}{l}\text { F: TGAACACGCCAACTGAGAATG } \\
\text { R: ACAGCTGCCCAATTCCTTGA }\end{array}$ & 2 & 2 & $205-215$ \\
\hline Frub61 & F.rubiginosa & $\begin{array}{l}\text { F: GTACACTCTCTTAGCTGCC } \\
\text { R: TACCTTTCTCTGGACATTC }\end{array}$ & 1 & M & 160 \\
\hline Frub93 & F.rubiginosa & $\begin{array}{l}\text { F: GATATTTCAATAACATCTCCTCAAC } \\
\text { R: TACGTTTGTTATGGACTTTGGC }\end{array}$ & NA & & - \\
\hline Frub391 & F.rubiginosa & $\begin{array}{l}\text { F: AGATGTCAAATAAGGTCAGCT } \\
\text { R: AGATGCAGTTCCATACAATTC }\end{array}$ & 1 & M & 164 \\
\hline Frub398 & F.rubiginosa & $\begin{array}{l}\text { F: GTACCTTAGATTCTAGTGTGAG } \\
\text { R: TGGGATCTCATGAACTATTTAC }\end{array}$ & 1 & M & 204 \\
\hline Frub412 & F.rubiginosa & $\begin{array}{l}\text { F: ACATCAAATTTCTTAGATCGGTTG } \\
\text { R: ATCCAGAGCGGCAAACACACAAG }\end{array}$ & 1 & M & 220 \\
\hline Frub415 & F.rubiginosa & F: GCACGTAGTCGGTGTTAAGC & 1 & M & 162 \\
\hline
\end{tabular}




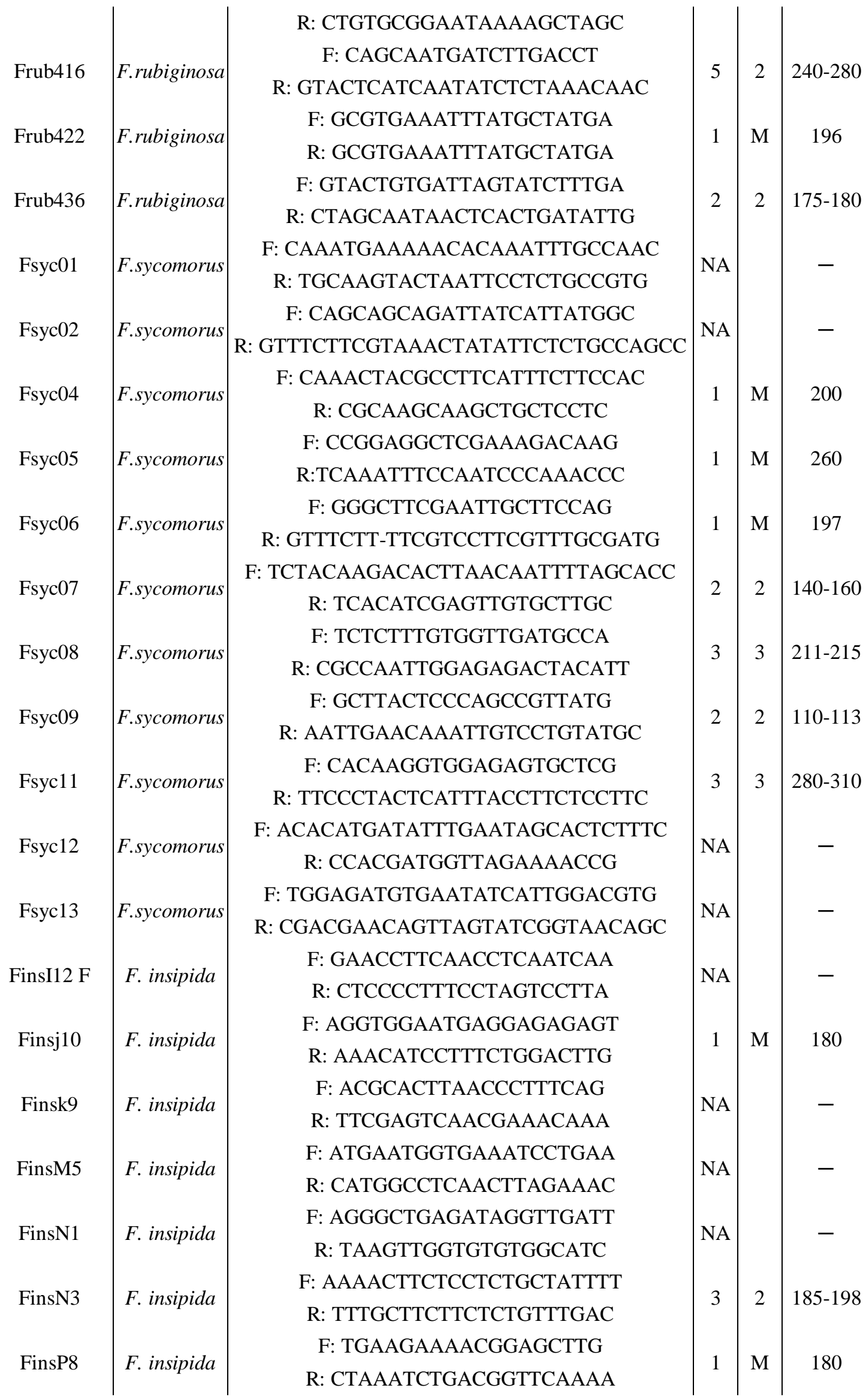




\begin{tabular}{|c|c|c|c|c|c|}
\hline FinsQ5 & F. insipida & $\begin{array}{l}\text { F: CATGTCAGGAGGTGTCTAGG } \\
\text { R: CTCCAAATGGGTATGTCAAG }\end{array}$ & 5 & 4 & $164-178$ \\
\hline FinsQ6 & F. insipida & $\begin{array}{l}\text { F: TTCTCCAATTAAACCTCCAA } \\
\text { R: CATGAAATCACCTTCCTCAT }\end{array}$ & 1 & M & 120 \\
\hline FinsT7 & F. insipida & $\begin{array}{l}\text { F: GAATCTGGAGGTGGAATAAAC } \\
\text { R: AAAGATCGCTCGTCAACC }\end{array}$ & NA & & - \\
\hline FinsU7 & F. insipida & $\begin{array}{l}\text { F: CGTGTATTGATGTGTGTGTG } \\
\text { R: TCACCTCCTCCTTCTTTTG }\end{array}$ & NA & & - \\
\hline FinsA1 & F. insipida & $\begin{array}{c}\text { F: AATCCCCGTACTTCACTTG } \\
\text { R: AGAACTTATTGCACGGACAG }\end{array}$ & 5 & 5 & $194-222$ \\
\hline FinsH5 & F. insipida & $\begin{array}{l}\text { F: GACCGTATAGATGATTTGGG } \\
\text { R: CATCCTGTGAACGACACTT }\end{array}$ & 1 & M & 270 \\
\hline FM4-15 & F. montana & $\begin{array}{l}\text { F: ATCTTCGTCGGTATTGCTTTCACT } \\
\text { R: GGAAGAGAACCCTTTTTGTATTGG }\end{array}$ & 14 & 14 & $200-285$ \\
\hline FM4-18 & F. montana & $\begin{array}{l}\text { F: CGTATGGCCCATGCTTGACTCAC } \\
\text { R: CTCGGATTGCCACGTGTAGGTTG }\end{array}$ & 1 & M & 185 \\
\hline FM1-27 & F. montana & $\begin{array}{l}\text { F: GTGATTTGCGATGGCGTGGTTTA } \\
\text { R: TCTTCGCTTGCTCGTCAGTGTCC }\end{array}$ & NA & & - \\
\hline FM3-64 & F. montana & $\begin{array}{l}\text { F: GATGGTGTTGTTGTCGATGGTCAT } \\
\text { R: GCGGCTCGGTGGAACTTGAG }\end{array}$ & NA & & - \\
\hline FM4-70 & F. montana & $\begin{array}{l}\text { F: CAGATGAGGTTGACGATGTTATTG } \\
\text { R: TAAACCCTCTTCAAATTCACTCTC }\end{array}$ & 7 & 6 & $202-232$ \\
\hline FS4-11 & F. septica & $\begin{array}{l}\text { F: AAGGCAACGGGGATAAAGTATTCA } \\
\text { R: CTCCGAGAGCAACTCCATCACG }\end{array}$ & NA & & - \\
\hline FS3-31 & F. septica & $\begin{array}{l}\text { F: CATCATCCCCGTCAGAAAGTGAGG } \\
\text { R: TGAGGCGGTGATGGTGATTGAAT }\end{array}$ & 2 & 2 & $240-242$ \\
\hline FS3-37 & F. septica & $\begin{array}{l}\text { F: CAAACGAGGAACAACACATACAGC } \\
\text { R: GATGCACAGGAGTTAACGGGAATG }\end{array}$ & NA & & - \\
\hline Total & & & 89 & 62 & \\
\hline
\end{tabular}

Seventeen SSR loci could distinguish the 32 fig genotypes with 62 alleles and UPGMA cluster analysis grouped these individuals into two main clusters with genetic similarity ranging from 0.63 to 0.80 . Cluster I is divided to two subclusters (1-A and 1B) at the similarity level of 0.65 and included 29 genotypes, while Cluster 2 consisted of 3 genotypes. 'Noire de Caromb' and 'Kavak' stayed on close to and grouped into Cluster I along with 'Beyaz Orak'. Two genotypes 'Armut İlek' and 'Bostanc1' were appeared to very close $(80 \%)$ on the dendrogram. Three genotypes, 'Sarılop', 'Sarıkilis' and 'Turnaboyu' separated from the majority of the genotypes and placed on the Cluster 2 (Fig. 1). The male and female genotypes were randomly placed on the dendrogram. Although a few female genotypes namely 'Noire de Cromb', 'Kavak', 'Beyaz Orak' and 'Mor özer' and male genotypes namely 'Derviş Ali', 'Kızılay', 'Bostancı' and 'Armut İlek' placed on together in a small cluster the rest of the genotypes clustered regardless of the gender (Fig. 1) The male and female genotypes were partly grouped in the two dimensional graph as well, a few male genotypes placed on the upper part and 
some female genotypes on the bottom of the matrix. But most of the male and female genotypes scattered randomly on the two dimensional graph as expected (Fig. 2).

\section{Discussion}

In current study overall, $70.37 \%$ (38/54) of the tested SSRs successfully amplified at least one PCR product in Ficus carica (Table 1). Mnejja et al. (2010) obtained similar results with Prunus and successfully transferred 63.9\% of SSRs to other Prunus species. Dirlewanger et al. (2002) transferred 41 primers developed in peach successfully to sweet cherry $(80.5 \%)$. In the present study, the highest transferability rate $(90.9 \%)$ was observed with SSRs developed for $F$. rubiginosa (Frub) and for $F$. racemosa (Frac). The transferability rate of Fsyc (F. sycomorus), FM (Ficus montana) and Fins (Ficus insipida) primers were $63.6 \%, 60 \%$ and $53.84 \%$, respectively. The lowest transferability rate $(33.3 \%)$ was obtained with SSRs developed for $F$. septica (FS). Nazareno et al. (2009) reported high transferability (80\%) of microsatellite markers developed from Ficus insipida (Fins), Ficus racemosa (Frac) and Ficus rubiginosa (Frub) to Ficus citrifolia and Ficus eximia. In present study, Frub loci developed for $F$. rubiginosa and Frac loci developed for $F$. racemose showed a high transferability rate. However, these two SSRs are monomorphic in both loci in the current studied population. They may produce polymorphic loci in different population.

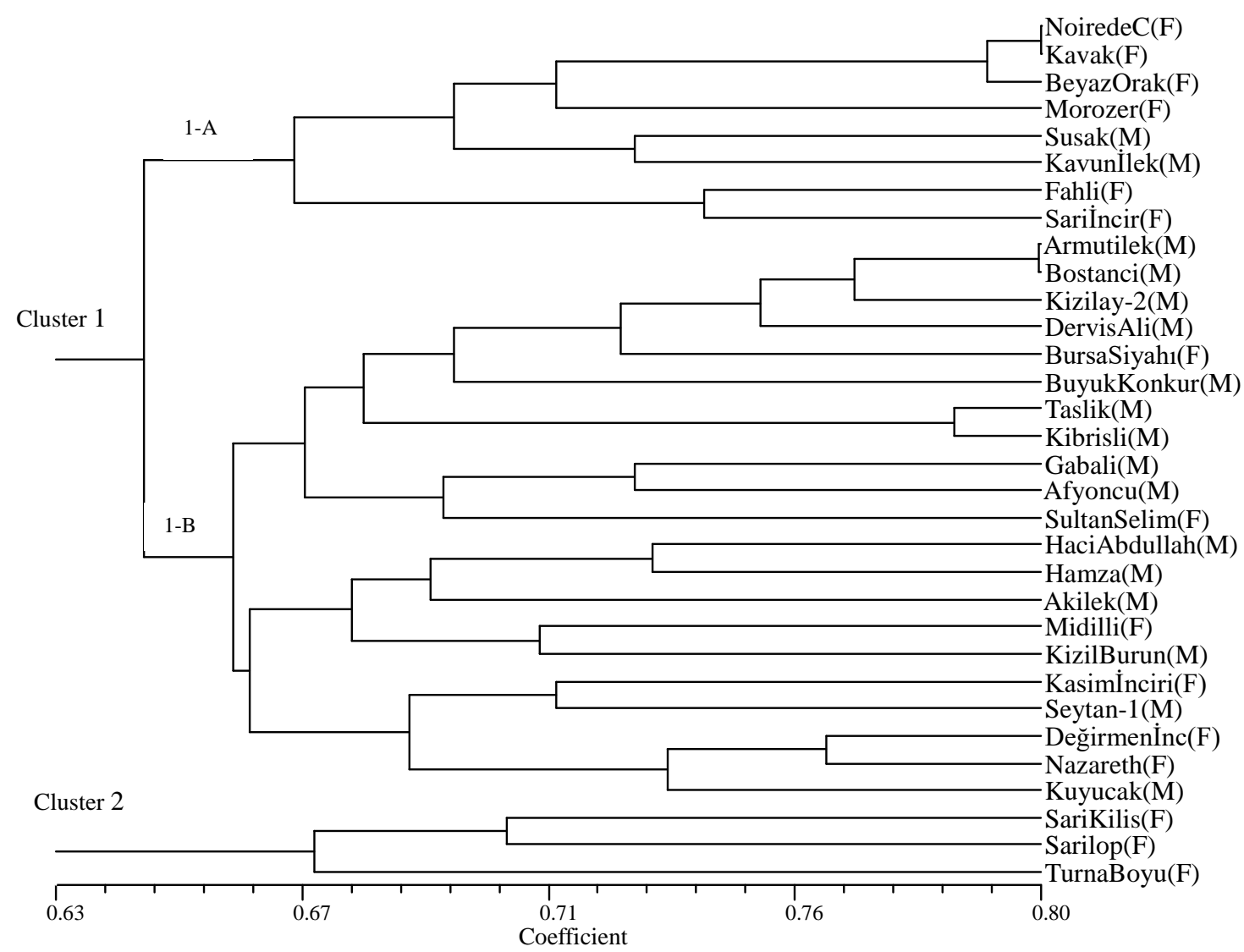

Figure 1. The dendrogram based on average distance coefficients among 32 individuals (16 female 16 male) with 62 SSR markers 


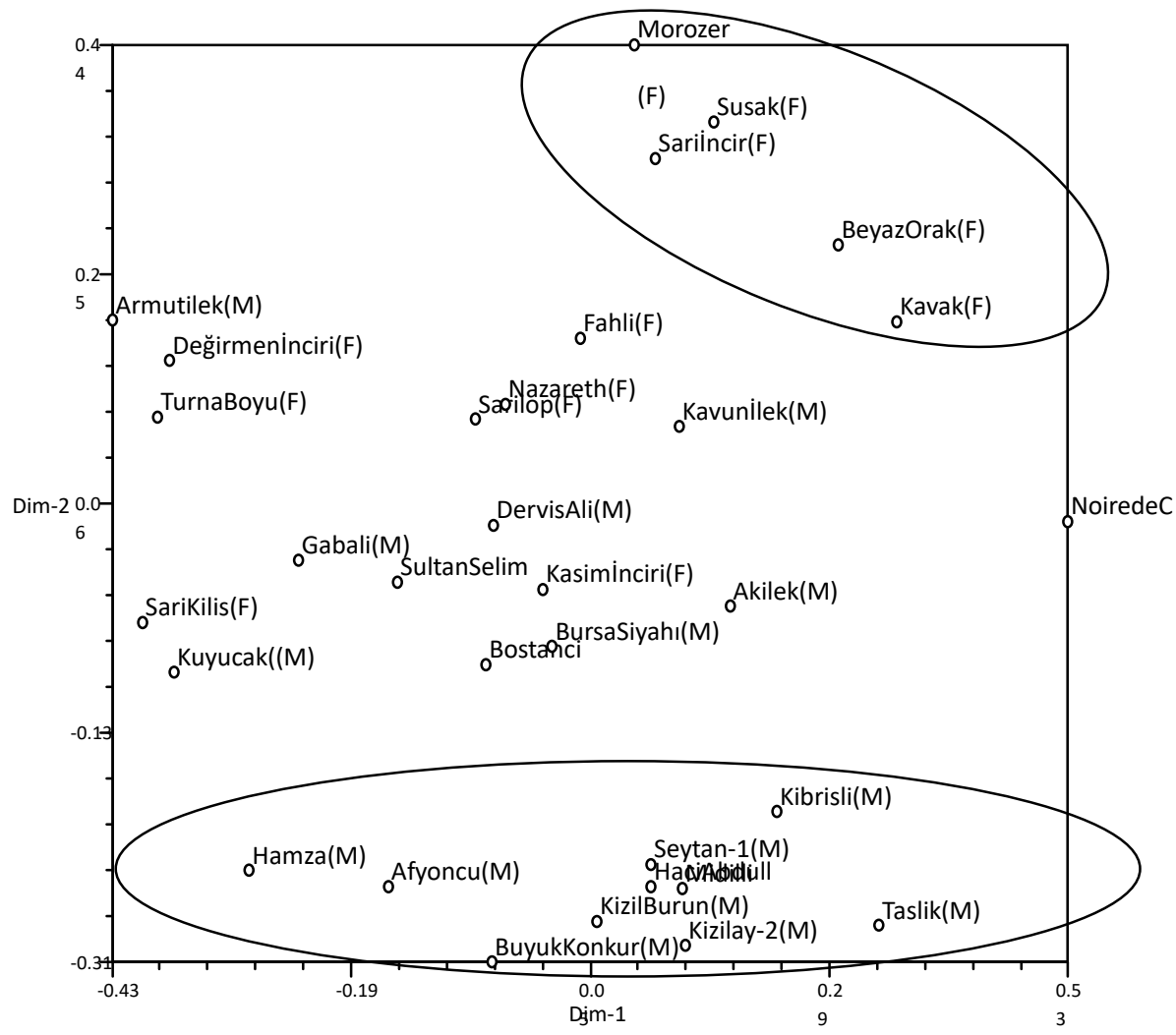

Figure 2. Two-dimensional plot from PCA of 32 fig genotypes (16 female, 16 male) analyzed with SSR markers

In current study 38 SSR loci produced 89 alleles with the 2.34 average alleles per locus. Comparing this results with previous studies; Giraldo et al. (2005) developed and tested 26 SSR loci on 15 Ficus carica cultivars and obtained 79 total bands with the average of 3 bands per SSR. The amplification pattern of the FM4-15 in our study was similar that of Zavodna et al. (2005) in which they obtained 14 alleles in donor species, Ficus montana. This may indicate that some of the region on Ficus carica and Ficus montana genome may be conserved. Of the 54 primers tested 16 did not amplify on Ficus carica. Similar result was reported by Giraldo et al. (2005). They tested 26 microsatellite SSR primers developed for Ficus carica on 13 different Ficus species and eight primers did not give amplification on Ficus species and they did give amplification on two Morus species.

Amplified markers from related species generally resulted in similar banding patterns in the Ficus carica genome, suggesting that they were developed from the same loci and primer binding sites are conserved. Similar alleles and length of amplification products were obtained with Frac13 (120, 135, 196), Frac83 (175-192-225), Frac 241 (280, 285, 294), Fsyc07 (140-160), FinsA1 (194-222), FM-4-15 (200-285) FM4-70 (202-232) when compared with the donor species (Crozier et al., 2007; Ahmed et al., 2007; Zavodna et al., 2005). There were some differences in a few SSR loci with the originally developed species and Ficus carica. Three loci (Fsyc11, FinsQ5 and FinsN3) produced more alleles in Ficus carica than the originally developed species (Ahmed et al., 2007; Vignes et al., 2006). Nazareno et al. (2009) indicated that most of the primers (Frac86, Frub29, Frub61, Frub391, Frub415, Frub422) produced more than one band in 
Ficus citrifolia and Ficus eximia whereas in the current study all of these primers amplified monomorphic bands in the Ficus carica (Table 1). This argued that the genetic diversity in Ficus carica may be less than Ficus citrifolia and Ficus eximia.

\section{Conclusion}

As a conclusion, 38 primers successfully transferred to Ficus carica of which 17 were polymorphic and produced 62 alleles. The polymorphic microsatellites are later employed to determine the genetic diversity among the Ficus carica genotypes. The produced 62 alleles discriminated the 32 Ficus carica genotypes successfully which shows the effectiveness of the markers.

Our results indicated a high level of transferability between Ficus carica and related Ficus species which provides a growing number of SSR for Ficus carica. This is an important benefit for species with genomic studies are limited. Transferred SSR markers can be used in the future studies for linkage and QTL mapping studies and molecular characterization of the genetic resources of Ficus carica. The 21 SSR primers produced monomorphic bands in the current studied population should be tested in the future studies to see the polymorphism levels in different population.

Acknowledgements. The authors thank to Erbeyli Fig Research Institute-Aydın, Turkey for research material and Akdeniz University for laboratory infrastructure and facilities.

\section{REFERENCES}

[1] Ahmed, S., Dawson, D. A., Compton, S., Gilmartin, P. (2007): Characterization of microsatellite loci in the African fig Ficus sycomorus L. (Moraceae). - Molecular Ecology Notes 7: 1175-1177.

[2] Condit, I. J. (1969): Ficus: The Exotic Species. - Division of Agricultural Sciences, University of California, California.

[3] Crozier, Y. C., Cheng, X., Yan Yao, J., Field, A. R., Cook, J. M., Crozier, R. H. (2007): Microsatellite primers for Ficus racemosa and Ficus rubiginosa. - Molecular Ecology Notes 7: 57-59.

[4] Darlington, C. D., Wylie, A. P. (1955): Chromosome Atlas of Flowering Plants, 2nd ed., pp. 183-185. - George Allen \& Unwin Ltd., London.

[5] Dirlewanger, E., Cosson, P., Tavaud, M., Aranzana, M. J., Poizat, C., Zanetto, A., Arús, P., Laigret, F. (2002): Development of microsatellite markers in peach [Prunus persica (L.) Batsch] and their use in genetic diversity analysis in peach and sweet cherry (Prunus avium L.). - Theor Appl Genet 105: 127-138.

[6] Doyle, J. J., Doyle, J. L. (1990): Isolation of plant DNA from fresh tissue. - Focus 12: 13-15.

[7] Fan, L., Zhang, M. Y., Liu, Q. Z., Li, L. T., Song, Y., Wang, L. F., Zhang, S. L., Wu. J. (2013): Transferability of newly developed pear SSR markers to other rosaceae species. Plant Mol Biol Rep 31: 1271-1282. DOI: 10.1007/s11105-013-0586-Z.

[8] Gasic, K., Han, Y., Kertbundit, S., Shulaev, V., Iezzoni, A. F., Stover, E. W., Bell, R. L., Wisniewski, M. E., Korban, S. S. (2009): Characteristics and transferability of new apple EST-derived SSRs to other Rosaceae species. - Mol Breed 23: 397-411.

[9] Giraldo, E., Viruel, M. A., Lopes-Corrales, M., Hormaza, J. I. (2005): Characterisation and cross-species transferability of microsatellites in the common fig (Ficus carica L.). Journal of Horticultural Science and Biotechnology 80: 217-224. 
[10] Heer, K., Machado, C. A., Himler, A. G., Herre, E. A., Kalko, E. K. V., Dick, C. W. (2012): Anonymous and EST-based microsatellite DNA markers that transfer broadly across the fig tree genus (Ficus, Moraceae). - American Journal of Botany: e330-e333 2012. http://www.amjbot.org/.

[11] Kuleung, C., Baenziger, P. S., Dweikat, I. (2004): Transferability of SSR markers among wheat, rye, and triticale. - Theor Appl Genet 108: 1147-1150. DOI: 10.1007/s00122003-1532-5.

[12] Mnejja, M., Garcia-Mas, J., Audergon, J. M., Arús, P. (2010): Prunus microsatellite marker transferability across rosaceous crops. - Tree Genetics \& Genomes 6: 689. DOI: 10.1007/s11295-010-0284-z.

[13] Nazareno, A. G., Pereira, R. A. S., Feres, J. M., Mestriner, M. A., Alzate-Marin, A. L. (2009): Transferability and characterization of microsatellite markers in two Neotropical Ficus species. - Genetics and Molecular Biology 32: 568-571.

[14] Pierantoni, L., Cho, K. H., Shin, I. S., Chiodini, R., Tartarini, S., Dondini, L., Kang, S. J., Sansavini, S. (2004): Characterisation and transferability of apple SSRs to two European pear F1 populations. - Theor Appl Genet 109: 1519-1524.

[15] Rahnavard, A. (2016): Genetic and biochemical diversity of Hypericum Perforatum L. grown in the Caspran climate of Iran. - Applied Ecology And Environmental Research 15(1): 665-675.

[16] Rohlf, J. F. (2000): NTSYS-pc: Numerical Taxonomy and Multivariate Analysis System. - Exeter Software, Setauket, New York.

[17] Schuelke, M. (2000): An economic method for the fluorescent labelling of PCR fragments. - Nature Biotechnology 18: 233-234.

[18] Storey, W. B. (1975): Figs. - In: Janick, J., Moore, J. N. (eds.) Advances in Fruit Breeding, pp. 568-589. Purdue University Press, West Lafayette, Indiana.

[19] Vignes, H., Hossa, M., Beaune, D., Fevre, D., Anstett, M. C., Borges, R. M., Kjellberg, F., Chevallier, M. H. (2006): Development and characterization of microsatellite markers for a monoecious Ficus species, Ficus insipida, and cross-species amplification among different sections of Ficus. - Molecular Ecology Notes 6: 792-795.

[20] Zavodna, M., Arens, P., Van, P. J., Vosman, B. (2005): Development and characterization of microsatellite markers for two dioecious Ficus species. - Molecular Ecology Notes 5: 355-357. 